\title{
MSC transplantation: a promising therapeutic strategy to manage the onset and progression of diabetic nephropathy
}

\author{
Marcelo E. Ezquer, Fernando E. Ezquer, Martha L. Arango-Rodríguez and Paulette A. Conget \\ Instituto de Ciencias, Facultad de Medicina Clínica Alemana-Universidad del Desarrollo. Av. Las Condes 12438, Lo Barnechea, Santiago, Chile.
}

\begin{abstract}
Currently, one of the main threats to public health is diabetes mellitus. Its most detrimental complication is diabetic nephropathy (DN), a clinical syndrome associated with kidney damage and an increased risk of cardiovascular disease. Irrespective of the type of diabetes, DN follows a well-known temporal course. The earliest detectable signs are microalbuminuria and histopathological changes including extracellular matrix deposition, glomerular basement membrane thickening, glomerular and mesangial expansion. Later on macroalbuminuria appears, followed by a progressive decline in glomerular filtration rate and the loss of glomerular podocytes, tubulointerstitial fibrosis, glomerulosclerosis and arteriolar hyalinosis. Tight glycemic and hypertension controls remain the key factors for preventing or arresting the progression of DN. Nevertheless, despite considerable educational effort to control the disease, a significant number of patients not only develop DN, but also progress to chronic kidney disease. Therefore, the availability of a strategy aimed to prevent, delay or revert DN would be highly desirable.

In this article, we review the pathophysiological features of DN and the therapeutic mechanisms of multipotent mesenchymal stromal cells, also referred to as mesenchymal stem cells (MSCs). The perfect match between them, together with encouraging pre-clinical data available, allow us to support the notion that MSC transplantation is a promising therapeutic strategy to manage DN onset and progression, not only because of the safety of this procedure, but mainly because of the renoprotective potential of MSCs.
\end{abstract}

Key words: Regenerative medicine. Diabetes mellitus. Diabetic nephropathy. Multipotent mesenchymal stromal cells. Mesenchymal stem cells.

According to the World Health Organization, the total number of people with diabetes mellitus (DM) is projected to rise from 285 million in 2010 to 439 million in 2030 (Shaw et al., 2010). Regarding its etiology, DM is classified as type 1 (T1DM) or type 2 (T2DM). While T1DM is due to autoimmune destruction of pancreatic beta cells leading to insulin deficiency (Cnop et al., 2005), T2DM is a metabolic disorder due to insulin resistance along with impaired insulin secretion (Cnop et al., 2005). Over the past decades, medical advances have substantially improved the management of patients with DM, thereby prolonging their survival (Penfornis et al., 2011). Nevertheless, available treatments do not guarantee a tight glycemic control, since patients do not often adhere well to medical indications. Thus even under treatment patients develop chronic macro- and microvascular diseases including stroke, neuropathy, retinopathy and nephropathy (Stolar, 2010; Maric and Hall, 2011). Among these, diabetic nephropathy (DN) is the most detrimental consequence with regard to both premature morbimortality and medical expenses (BlazquezMedela et al., 2010; Stolar, 2010). Furthermore, DN represents a major concern for public health worldwide, since $25 \%$ to $40 \%$ of the patients with DM develop it, and also because as DN progresses to end-stage chronic kidney disease, patients require hemodialysis and even kidney transplant (McCrary, 2008; Reutens and Atkins, 2011).

\section{PATHOPHYSIOLOGICAL FEATURES OF DIABETIC NEPHRO- PATHY}

DN is a clinical syndrome consisting of kidney damage and increased risk of cardiovascular diseases. Its main risk factors are gender, genetic factors, renal hemodynamics and age of DM onset (Blazquez-Medela et al., 2010). Although the time of clinical debut of DN varies between patients with T1DM and T2DM, clinical and histological progressions in both conditions are quite similar (Najafian et al., 2011). Changes in the filtration unit begin soon after DM onset, and take place "silently" for a long time before the appearance of the first clinical signs of the disease. In susceptible patients DN follows a well-known physiopathological course (Figure 1). Microalbuminuria is the earliest clinically detectable sign of kidney damage. It is associated with histological changes that include extracellular matrix deposition, glomerular basement membrane thickening and glomerular mesangial expansion. In later stages patients develop macroalbuminuria, followed by a progressive decline in the glomerular filtration rate. At this stage, histological changes include glomerulosclerosis, tubulointerstitial fibrosis and arteriolar hyalinosis (Najafian et al., 2011).

Although hyperglycemia itself is not sufficient to provoke development of $\mathrm{DN}$, the main promoting factors are the following metabolic and hemodynamic alterations (Figure 1):

- augmented oxidative stress. High glucose flux increases the production of superoxide anions in the mitochondrial electron transport chain (Rolo and Palmeira, 2006). Excessive production of superoxide anions results in the formation of more superoxide anion and secondary reactive oxygen species (ROS) including peroxynitrite and hydroxyl radicals, which modify DNA, proteins and lipids (Brownlee, 2001). Along with a deregulation of anti-oxidant enzymes, increased oxidative stress leads to endothelial damage (Evans et al., 2002). Furthermore, ROS up-regulate 
the expression of TGF-beta1, PAI-1 and extracellular matrix (ECM) proteins in glomerular mesangial cells, triggering mesangial expansion (Fujita et al., 2009).

- accumulation of advanced glycation end products and fibrosis. High glucose concentration results in nonenzymatic glycation of proteins, lipids and nucleic acids (Yamagishi and Matsui, 2010). These advanced glycation end products (AGEs) interact with membrane receptors that induce crosslinking of ECM proteins and slow down their turnover. Thus the normal interactions among ECM proteins are disrupted in a way that compromises their function and leads to fibrosis. Furthermore, aberrant cellECM interactions lead to the alteration of cell adhesion, proliferation and epithelial phenotype maintenance, stimulating epithelial-to-mesenchymal transition (Simonson, 2007; Yamagishi and Matsui, 2010). In addition, AGEs induce ROS synthesis and ROS accelerate AGE formation (Singh et al., 2011). This positive feedback between AGEs and ROS worsens renal tissue damage.

- chronic inflammation. DN was considered to be a nonimmune disease. Nevertheless, it has been shown recently that inflammation is crucial for the development of microvascular complications of DM, including nephropathy (Mora and Navarro, 2006; Ortiz-Munoz et al., 2010).
Accordingly, lymphocytes, monocytes and macrophages have been involved in DN progression (Galkina and Ley, 2006; Ninichuk et al., 2007). Moreover, it has been proved that IL-1beta, IL-6 and TNF-alpha are relevant for the development of DN (Mocan et al., 2006; Mora and Navarro, 2006). IL-1beta and IL-6 increase vascular endothelial permeability and alter ECM dynamics at both the mesangial and podocyte levels, contributing to interstitial infiltrates, glomerular basement membrane thickening, mesangial expansion, and tubular atrophy (Pecoits-Filho et al., 2002; Dalla et al., 2005). TNF-alpha is cytotoxic to renal cells and contributes to sodium retention and renal hypertrophy, alterations that are observed during the earlier stages of DN (DiPetrillo et al., 2004). Also, the exposure of tubular epithelial cells to TNF-alpha results in a significant increase in the synthesis and secretion of lymphocyte- and neutrophil-chemoattractant factors, and in the cell surface expression of ICAM-1 (Ishikura et al., 1991). Accordingly, the up-regulation of MCP-1 and ICAM-1 in the kidney has been associated with macrophage and lymphocyte recruitment, urinary albumin excretion, tubulointerstitial injury and DN progression (Matsui et al., 1996; Chow et al., 2006). In addition, TNF-alpha directly promotes the local generation of ROS, resulting in the alteration of the function of glomerular capillary barrier wall, which allows the permeation of albumin (McCarthy et al., 1998).

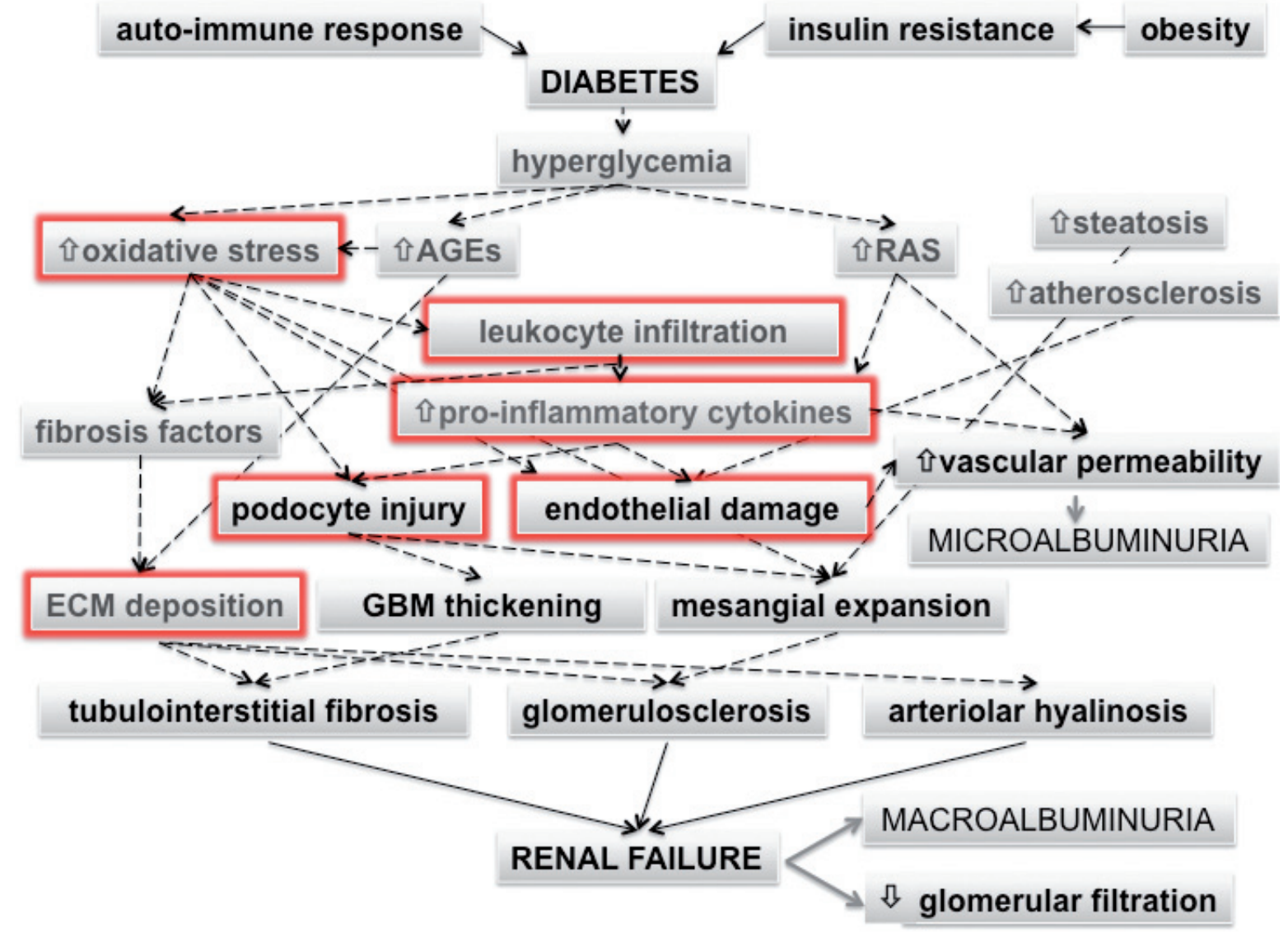

Figure 1. Pathophysiological features triggered at the onset and required for the maintenance of DN: The putative therapeutic targets of donor MSC that might contribute to the prevention, delay or reversion of DN are highlighted in red.

AGEs: advanced glycation end products, RAS: renin-angiotensin system, ECM: extracellular matrix, GBM: glomerular basement membrane. 
- altered renin-angiotensin system. Angiotensin II shows increased activity during DN, and causes hypertrophy of mesangial and tubular epithelial cells (Chawla et al., 2010). Also, it has pressor effects on arteriolar smooth muscle, increasing vascular pressure. Furthermore, Angiotensin II induces inflammation, apoptosis and promotes the production of TGF-beta and MCP-1, two prosclerotic cytokines that have been identified as responsible for glomerular sclerosis.

- steatosis and atherosclerosis. Patients with T2DM present additional factors that aggravate renal damage, i.e. obesity, dyslipidemia, atherosclerosis that results in renal ischemia and hypertension (Maric and Hall, 2011; Packham et al., 2011). Lipid deposition in the kidneys produces direct glomerular injury, and may also result in glomerular mesangial cell activation and proliferation (Wang et al., 2005). Activation of these cells leads to chemokine production, which promotes the recruitment of monocytes and their maturation into macrophages in the mesangium. Furthermore, it has been shown that renal mesangial and tubular cells grown in culture and incubated with LDL or VLDL up-regulate the expression of TGF-beta and PAI-1 and accumulate ECM proteins (Vaziri and Norris, 2011), thus demonstrating that lipids have a direct role in the activation of glomerulosclerosis mediators.

\section{AVAILABLE STRATEGIES TO MANAGE PATIENTS WITH DIA- BETIC NEPHROPATHY}

There is currently no cure for patients with DN. Palliative therapeutic strategies include the use of drugs to control hyperglycemia, blood pressure and proteinuria (Yamagishi et al., 2007; Choudhury et al., 2010). In advanced stages patients receive renal replacement therapy, which consists of hemodialysis and, if possible, kidney transplantation (Reutens and Atkins, 2011). Unfortunately, the latter is only useful when the kidney is co-transplanted with pancreatic beta-islets; if this is not done, renal failure reappears (Fioretto and Mauer, 2012). Therefore, the need for therapeutic strategies to prevent, delay or revert $\mathrm{DN}$ is compelling.

\section{STEM CELL-BASED STRATEGIES TO MANAGE PATIENTS WITH DIABETIC NEPHROPATHY}

Pharmacological interventions often target only a single pathophysiological feature of the disease, e.g. the inhibitors of the renin-angiotensin system used for the management of patients with DN suppress urinary albumin excretion in a relatively short term but do not prevent renal function decline and the progression to end-stage chronic kidney disease (Jerums et al., 2008). Conversely, stem cell-based intervention is known to act through multiple mechanisms, a clear advantage when facing diseases with highly complex pathophysiology, as is the case of DN. Choosing the adequate stem cell for this purpose should take into account the following notions:

- embryonic stem cells are obtained from the inner cell mass of a blastocyst and are pluripotent; i.e., they can give rise to endo-, meso- and ectodermal cells. Their teratogenicity raises a major concern regarding biosafety. Bioethical, religious and political issues have limited the studies aimed to evaluate their putative massive therapeutic use (Mertes and Pennings, 2009).

- induced pluripotent stem cells are generated after somatic cell reprogramming (Takahashi et al., 2007). These cells are pluripotent and teratogenic, thus they share the biosafety concerns with embryonic stem cells. To avoid this problem, researchers have proposed that pluripotent stem cells should be first differentiated in vitro and then transplanted. This imposes at least two major technical problems to solve; the definition of proper and efficient differentiation conditions, and the development of procedures for the delivery of differentiated cells into damaged tissues.

- adult stem cells are found in all non-embryonic tissues; hence they may be isolated from fetus, newborn, child and adult individuals. They contribute to both maintenance of cellular homeostasis and regeneration of damaged organs. Adult stem cells are multipotent, and due to their limited self-renewal potential, not teratogenic. Some of them also have plasticity, i.e., they can differentiate into cells from lineages different from their origin (Phinney and Prockop, 2007).

Since adult stem cells pose less bioethical and technical concerns, the first candidate for a stem cell-based strategy to treat DN was bone marrow-derived stem cells. These cells have shown to contribute to the regeneration of damaged kidneys (Kale et al., 2003; Poulsom et al., 2003). Accordingly, bone marrow-derived stem cells have been shown to differentiate or transdifferentiate into mesangial cells (Ito et al., 2001; Imasawa et al., 2001), tubular epithelial cells (Poulsom et al., 2001), endothelial cells (Rookmaaker et al., 2003), and podocytes (Prodromidi et al., 2006).

Bone marrow harbors at least two distinct adult stem cells; the hematopoietic stem cells that give rise to blood and endothelial cells (Wagers and Weissman, 2004) and the multipotent mesenchymal stromal cells, also referred to as mesenchymal stem cells (MSCs), that give rise to adipocytes, chondrocytes, osteocytes and myocytes (Minguell et al., 2001; Dominici et al., 2006). Additionally, it has been suggested that MSCs might cross the germ line barrier and generate cells from the endo- and ectodermal lineages (Phinney and Prockop, 2007).

The main advantage of MSCs over hematopoietic stem cells for clinical use is their hypoimmunogenicity, since histocompatibility between donor and receptor is not required. Also, recipients do not need to be conditioned before MSC transplantation, as is the case in total bone marrow or hematopoietic stem cell transplantation (Uccelli et al., 2008). Furthermore, it is currently agreed that MSCs contribute to tissue regeneration not only because of their differentiation potential, but also because of the following therapeutic mechanisms (Figure 2):

- scavenging of oxidative stress. MSCs are highly resistant to ex vivo culture and ionizing radiation, which are two conditions that generate strong oxidative stress. Recently we demonstrated that the low susceptibility of MSCs to the deleterious effect of ROS and reactive nitrogen species correlates with the ability of these cells to effectively scavenge peroxide and peroxynitrite, due to the constitutive expression of SOD1, SOD2, CAT and 
GPX1 enzymes and high levels of glutathione (Valle-Prieto and Conget, 2010). Moreover, MSCs possess the main enzymatic mechanisms to detoxify reactive species and to prevent oxidative damage of the proteome and genome (Salmon et al., 2009). Thus, MSCs are endowed with the main molecular mechanisms to manage oxidative stress efficiently.

- anti-fibrosis. The role of MSCs in fibrosis is still a matter of controversy. Some studies have indicated that MSCs have no effect, others show an increase and others show a decrease (Carvalho et al., 2008; di Bonzo et al., 2008; Ezquer et al., 2011). These differences may be related, at least in part, to the characteristics of target tissues, fibrosis etiology, the stage of disease at the moment of MSC administration and follow up time. The anti-fibrosis effect of MSCs could be direct, i.e. through the regulation of ECM protein

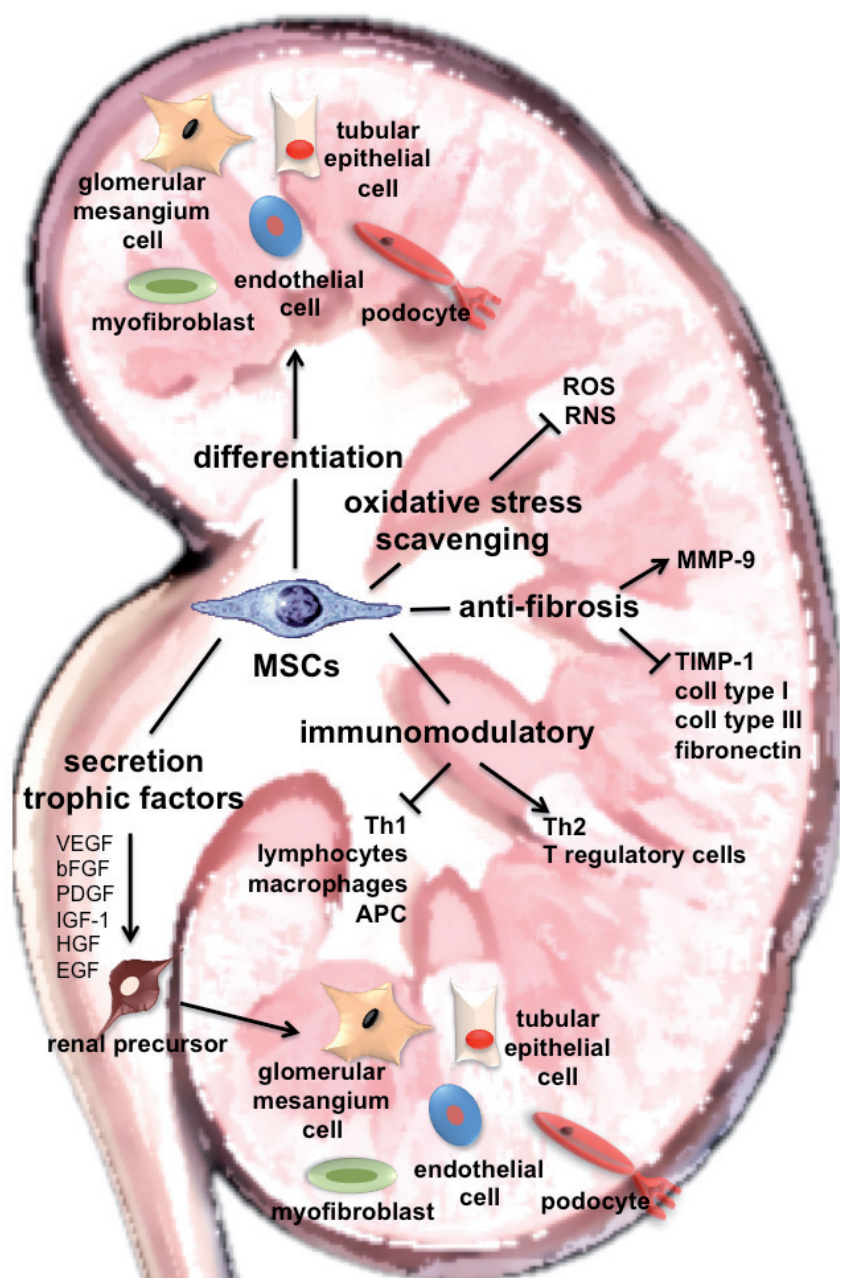

Figure 2. Predictable cellular and molecular mechanisms underlying MSC renoprotection: Once administered into an individual with DN, MSCs will circulate into the bloodstream. In damaged kidney, they will cross the endothelium, home into the parenchyma and migrate to the injured areas. MSCs will contribute to renal tissue regeneration through, at least, one of the mechanisms shown in the figure.

ROS: reactive oxygen species, RNS: reactive nitrogen species, APC: antigen presenting cell. synthesis and degradation, or indirect, i.e. due to the preclusion of leukocyte infiltration and/or the inhibition of pro-fibrotic cytokine secretion (Higashiyama et al., 2007; Semedo et al., 2009a).

- immunomodulation. MSCs express constitutively major histocompatibility complex class I, and after induction major histocompatibility complex class II (Rasmusson, 2006). However, they do not present in the cell surface costimulatory molecules such as B7-1, B7-2, CD40 y CD40L. Hence, they activate neither allogeneic lymphocytes nor a proliferative response in helper CD4+ T lymphocytes, and they are not targeted by CD8+ cytotoxic T lymphocytes (Tse et al., 2003). Furthermore, MSCs are capable of inhibiting the differentiation of monocyte precursors into activating dendritic cells, and of altering the function of mature dendritic cells (Jiang et al., 2005). Thus MSCs indirectly limit the cytotoxic expansion and activity of NK cells and $\mathrm{T}$ lymphocytes. And last but not least, MSCs promote the appearance of regulatory $\mathrm{T}$ lymphocytes, inducing antigenspecific tolerance (Maccario et al., 2005). MSCs reduce the serum levels of IL-5, IL-12(p40) and TNF-alpha, resulting in a reduction of leukocyte infiltration into damaged tissues (Togel et al., 2005; Semedo et al., 2009b). In addition, MSC administration leads to modulation of the inflammation through down-regulation of the Th1 cytokines (IL-1beta, IL-6, IL-12, TNF-alpha and INF-gamma), and up-regulation of Th2 cytokines (IL-4 and IL-10) (Semedo et al., 2009b).

- secretion of trophic factors. It is known that MSCs have the ability to secrete in vivo and in vitro a wide range of trophic factors, including VEGF, bFGF, PDGF, IGF-1, HGF and EGF (Caplan and Dennis, 2006). The biological effect of these factors can be both direct, i.e. triggering intracellular signalling in the target cell, or indirect, i.e. inducing neighbor cells to secrete bioactive factors. Therefore it has been proposed that MSCs have a catalytic role in tissue regeneration, since once in the damaged tissue they are able to modify the microenvironment by secreting factors that would: (i) prevent parenchymal cells from dying; e.g. anti-apoptotic factors such as HGF and IGF, in models of myocardial infarction and acute renal failure (Nigam and Lieberthal, 2000; Kinnaird et al., 2004b); (ii) induce the proliferation and differentiation of endogenous progenitors; e.g. neurogenic factors such as NGF and BDNF, in models of neuronal damage (Neuhuber et al., 2005); (iii) promote neovascularization; e.g. angiogenic and vasculogenic factors such as VEGF and bFGF, in models of acute myocardial infarction and ischemic acute renal failure (Kinnaird et al,. 2004a; Togel et al., 2007).

MSC TRANSPLANTATION: A PROMISING STRATEGY TO MANAGE PATIENTS WITH DIABETIC NEPHROPATHY

General support

Although MSCs are scarce (less than $0.01 \%$ in the bone marrow), they appear as ideal candidates to prevent, delay or revert $\mathrm{DN}$, since (i) they can be obtained from donors without major complications; (ii) they can be expanded ex vivo; (iii) they are hypoimmunogenic; (iv) once administered intravenously, they are able to home into damaged organs where they may protect the parenchyma from noxa, organize endogenous 
regenerative mechanisms and/or differentiate into tissuespecific cells (Figure 2). Furthermore, MSC transplantation has been successfully performed in human patients to treat diverse pathologies such as graft-versus-host disease (Le Blanc et al., 2004), cerebral stroke (Bang et al., 2005), myocardial infarction (Gnecchi et al., 2005; Ripa et al., 2007), metachromatic leukodystrophy (Koc et al., 2002), idiopathic aplastic anemia (Fouillard et al., 2003), osteogenesis imperfecta (Le Blanc et al., 2005) and dystrophic epidermolysis bullosa (Conget et al., 2010). So far MSCs have been administered to more than 1,000 human patients with no evidence of adverse effects or tumor formation.

\section{Indirect support}

Indirect support for the putative contribution of donor MSC to the management of individuals with DN includes: (i) recipient MSCs play a key role in normal turnover and remodeling of renal structures including renal vessels, interstitial myofibroblast cells, glomerular mesangium, podocytes and tubular epithelium (Cornacchia et al., 2001; Grimm et al., 2001; Poulsom et al. 2001; Gupta et al., 2002); (ii) in mice models of Alport syndrome and glomerulonephropathy, MSC administration results in clinical improvements (Sugimoto et al., 2006; Wong et al., 2008); (iii) in rodent models of acute tubular epithelial injury and experimental glomerulonephritis, donor MSCs contribute to the functional and structural recovery of both glomerular and tubular compartments (Morigi et al., 2004; Krause and Cantley, 2005; Qian et al., 2008); (iv) in rat remnant kidney models, MSC transplantation attenuates renal fibrosis and produces a reduced glomerulosclerosis index (Semedo et al., 2009a). This was correlated with a reduction in the expression of pro-fibrotic molecules such as collagen type I, collagen type III, fibronectin, vimentin, ASMA, FSP-1 and TGF-beta. It was also associated with a change of the ratio between MMP-9 and TIMP-1, indicative of recovery in the balance between synthesis and degradation of ECM components; (v) in animal models of acute kidney injury MSC transplantation was beneficial (Lange et al., 2005). It was also observed that IGF-1 produced by MSCs reduces apoptosis and increases cell proliferation of the proximal tubular epithelium, whereas HGF secreted by MSCs enhances the remodeling of fibrotic renal tissue (Imberti et al., 2007); (vi) ongoing clinical trials are assessing the safety and efficacy of MSCs to treat cisplastininduced acute renal failure and lupus nephritis (Giordano et al., 2007; www.clinicaltrials.gov).

\section{Direct support}

To our knowledge, there are only four published reports showing, at the pre-clinical level, that MSC-based therapy could be useful for the prevention or the reversion of renal failure in diabetic individuals. In an immunodeficient nonobese diabetic mouse model, it has been shown that after the intracardiac injection of a large number of human MSCs $\left(\approx 250 \times 10^{6} / \mathrm{kg}\right.$ body weight $)$, few donor cells were found in the kidneys (Lee et al., 2006). Unfortunately, it is not known whether this had any functional consequence, as animals did not present renal failure before the intervention or during the follow-up period. In mice with T1DM induced by the administration of five low doses of streptozotocin, we showed that the intravenous administration of syngeneic MSCs $\left(\approx 20 \times 10^{6} / \mathrm{kg}\right.$ body weight) results in the reduction of microalbuminuria and the preservation of normal renal histology (Ezquer et al., 2008). By contrast, untreated diabetic mice remained albuminuric and presented glomerular hyalinosis and mesangial expansion. In rats with diabetes induced by the administration of a single high dose of streptozotocin, the intracardiac infusion of allogeneic MSCs $\left(\approx 10 \times 10^{6} / \mathrm{kg}\right.$ body weight) along with cyclosporine resulted in a transient amelioration of renal function and structure (Zhou et al., 2009). In the latter two reports, after MSC administration an improvement in the diabetes condition was also observed. To determine whether the renoprotective effect of MSCs is indirect, i.e. due to hyperglycemia correction, or direct, i.e. due to protection/regeneration of renal tissue, we administered syngeneic MSCs in a mouse model that develops severe diabetes after the infusion of a single high dose of streptozotocin (Ezquer et al., 2009). Despite not sharing the etiology of either T1DM or T2DM, these animals showed a rapid progression of renal failure and developed most of the pathognomonic signs of DN. In these diabetic mice, MSC administration did not result in hyperglycemia correction; however, renal failure did not progress. In contrast, in untreated diabetic mice microalbuminuria gradually increased and renal histopathological alterations were evident at the end of the study period. Interestingly, at least up to three months after MSC administration donor cells were found in the kidney of severe diabetic mice. None of the published reports explored the mechanisms behind renoprotection. But, due to the scarce numbers of donor cells found in recipient kidneys, it is expected that mechanisms different than cell differentiation will be relevant.

\section{Potential limitations to clinical translation}

Data supporting the contribution of donor MSCs to the management of renal failure in diabetic individuals have been generated in the available animal models of $\mathrm{DN}$. Unfortunately, those models only reproduce the earlier stages of human DN (Breyer et al., 2005; Inada et al., 2005; Alpers and Hudkins, 2011). Non-obese and streptozotocin-induced diabetic mice progress to proteinuria and hyperfiltration. They also present variable degrees of mesangial matrix expansion and glomerular capillary basement membrane thickening, but infrequently develop nodular glomerulosclerosis, a pathognomonic sign of advanced human DN. Hence the impact of MSC transplantation in individuals with advanced $\mathrm{DN}$ remains unproved.

No dose-response studies have been performed, since the optimal dose of MSCs is unknown. Also, the cellular and molecular mechanisms behind MSC renoprotection in a diabetic environment are still unidentified. Thus more preclinical and clinical trials should be designed and performed in order to assess the safety and efficacy of MSC transplantation in individuals with DN.

\section{CONCLUSION}

The perfect match between the pathophysiological features of $\mathrm{DN}$ and the therapeutic mechanisms of MSCs, together with the encouraging pre-clinical data available supports the notion that MSC transplantation is a promising therapeutic strategy 
to manage DN onset and progression, not only because of the safety of this procedure, but mainly because of the renoprotective potential of MSCs.

\section{ACKNOWLEDGEMENTS}

Supported by FONDECYT Grant \# 1120133 to M.E. We thank Mrs. Carolina Larraín for English editing of the manuscript.

\section{DISCLOSURE OF POTENTIAL CONFLICTS OF INTEREST}

The authors declare no potential conflicts of interest.

\section{REFERENCES}

ALPERS CE, HUDKINS KL (2011) Mouse models of diabetic nephropathy. Curr Opin Nephrol Hypertens 20:278-284.

BANG OY, LEE JS, LEE PH, LEE G (2005) Autologous mesenchymal stem cell transplantation in stroke patients. Ann Neurol 57:874-882.

BLÁZQUEZ-MEDELA AM, LÓPEZ-NOVOA JM, MARTÍNEZ-SALGADO C (2010) Mechanisms involved in the genesis of diabetic nephropathy. Curr Diabetes Rev 6:68-87.

BREYER MD, BOTTINGER E, BROSIUS FC, III, COFFMAN TM, HARRIS RC, HEILIG CW, SHARMA K (2005) Mouse models of diabetic nephropathy. J Am Soc Nephrol 16:27-45.

BROWNLEE M (2001) Biochemistry and molecular cell biology of diabetic complications. Nature 414:813-820.

CAPLAN AI, DENNIS JE (2006) Mesenchymal stem cells as trophic mediators. J Cell Biochem 98:1076-1084.

CARVALHO AB, QUINTANILHA LF, DIAS JV, PAREDES BD, MANNHEIMER EG, CARVALHO FG, ASENSI KD, GUTFILEN B, FONSECA LM, RESENDE CM, REZENDE GF, TAKIYA CM, DE CARVALHO AC, GOLDENBERG RC (2008) Bone marrow multipotent mesenchymal stromal cells do not reduce fibrosis or improve function in a rat model of severe chronic liver injury. Stem Cells 26:1307-1314.

CHAWLA T, SHARMA D, SINGH A (2010) Role of the renin angiotensin system in diabetic nephropathy. World J Diabetes 1:141-145.

CHOUDHURY D, TUNCEL M, LEVI M (2010) Diabetic nephropathy -a multifaceted target of new therapies. Discov Med 10:406-415.

CHOW FY, NIKOLIC-PATERSON DJ, OZOLS E, ATKINS RC, ROLLIN BJ, TESCH GH (2006) Monocyte chemoattractant protein-1 promotes the development of diabetic renal injury in streptozotocin-treated mice. Kidney Int 69:73-80.

CNOP M, WELSH N, JONAS JC, JORNS A, LENZEN S, EIZIRIK DL (2005) Mechanisms of pancreatic beta-cell death in type 1 and type 2 diabetes: many differences, few similarities. Diabetes 54:Suppl 2 S97-107.

CONGET P, RODRÍGUEZ F, KRAMER S, ALLERS C, SIMON V, PALISSON F, GONZALEZ S, YUBERO MJ (2010) Replenishment of type VII collagen and re-epithelialization of chronically ulcerated skin after intradermal administration of allogeneic mesenchymal stromal cells in two patients with recessive dystrophic epidermolysis bullosa. Cytotherapy 12:429-431.

CORNACCHIA F, FORNONI A, PLATI AR, THOMAS A, WANG Y, INVERARDI L, STRIKER LJ, STRIKER GE (2001) Glomerulosclerosis is transmitted by bone marrow-derived mesangial cell progenitors. J Clin Invest 108:1649-1656.

DALLA VM, MUSSAP M, GALLINA P, BRUSEGHIN M, CERNIGOI AM, SALLER A, PLEBANI M, FIORETTO P (2005) Acute-phase markers of inflammation and glomerular structure in patients with type 2 diabetes. J Am Soc Nephrol 16:Suppl 1 S78-S82.

DI BONZO LV, FERRERO I, CRAVANZOLA C, MARESCHI K, RUSTICHELL D, NOVO E, SANAVIO F, CANNITO S, ZAMARA E, BERTERO M, DAVIT A, FRANCICA S, NOVELLI F, COLOMBATTO S, FAGIOLI F, PAROLA M (2008) Human mesenchymal stem cells as a two-edged sword in hepatic regenerative medicine: engraftment and hepatocyte differentiation versus profibrogenic potential. Gut 57:223-231.

DIPETRILLO K, COUTERMARSH B, SOUCY N, HWA J, GESEK F (2004) Tumor necrosis factor induces sodium retention in diabetic rats through sequential effects on distal tubule cells. Kidney Int 65:1676-1683.

DOMINICI M, LE BK, MUELLER I, SLAPER-CORTENBACH I, MARINI F, KRAUSE D, DEANS R, KEATING A, PROCKOP D, HORWITZ E (2006) Minimal criteria for defining multipotent mesenchymal stromal cells. The International Society for Cellular Therapy position statement. Cytotherapy 8:315-317.

EVANS JL, GOLDFINE ID, MADDUX BA, GRODSKY GM (2002) Oxidative stress and stress-activated signaling pathways: a unifying hypothesis of type 2 diabetes. Endocr Rev 23:599-622.

EZQUER F, EZQUER M, SIMON V, PARDO F, YÁÑEZ A, CARPIO D, CONGET P (2009) Endovenous administration of bone-marrow-derived multipotent mesenchymal stromal cells prevents renal failure in diabetic mice. Biol Blood Marrow Transplant 15:1354-1365.

EZQUER FE, EZQUER ME, PARRAU DB, CARPIO D, YÁÑEZ AJ, CONGET PA (2008) Systemic administration of multipotent mesenchymal stromal cells reverts hyperglycemia and prevents nephropathy in type 1 diabetic mice. Biol Blood Marrow Transplant 14:631-640.

EZQUER M, EZQUER F, RICCA M, ALLERS C, CONGET P (2011) Intravenous administration of multipotent stromal cells prevents the onset of non-alcoholic steatohepatitis in obese mice with metabolic syndrome. J Hepatol 55:1112-1120.

FIORETTO P, MAUER M (2012) Reversal of diabetic nephropathy: lessons from pancreas transplantation. J Nephrol 25:13-18.

FOUILLARD L, BENSIDHOUM M, BORIES D, BONTE H, LÓPEZ M, MOSELEY AM, SMITH A, LESAGE S, BEAUJEAN F, THIERRY D, GOURMELON P, NAJMAN A, GORIN NC (2003) Engraftment of allogeneic mesenchymal stem cells in the bone marrow of a patient with severe idiopathic aplastic anemia improves stroma. Leukemia 17:474476.

FUJITA H, FUJISHIMA H, CHIDA S, TAKAHASHI K, QI Z, KANETSUNA Y, BREYER MD, HARRIS RC, YAMADA Y, TAKAHASHI T (2009) Reduction of renal superoxide dismutase in progressive diabetic nephropathy. J Am Soc Nephrol 20:1303-1313.

GALKINA E, LEY K (2006) Leukocyte recruitment and vascular injury in diabetic nephropathy. J Am Soc Nephrol 17:368-377.

GIORDANO A, GALDERISI U, MARINO IR (2007) From the laboratory bench to the patient's bedside: an update on clinical trials with mesenchymal stem cells. J Cell Physiol 211:27-35.

GNECCHI M, HE H, LIANG OD, MELO LG, MORELLO F, MU H, NOISEUX N, ZHANG L, PRATT RE, INGWALL JS, DZAU VJ (2005) Paracrine action accounts for marked protection of ischemic heart by Akt-modified mesenchymal stem cells. Nat Med 11:367-368.

GRIMM PC, NICKERSON P, JEFFERY J, SAVANI RC, GOUGH J, MCKENNA RM, STERN E, RUSH DN (2001) Neointimal and tubulointerstitial infiltration by recipient mesenchymal cells in chronic renal-allograft rejection. N Engl J Med 345:93-97.

GUPTA S, VERFAILLIE C, CHMIELEWSKI D, KIM Y, ROSENBERG ME (2002) A role for extrarenal cells in the regeneration following acute renal failure. Kidney Int 62:1285-1290.

HIGASHIYAMA R, INAGAKI $Y$, HONG YY, KUSHIDA M, NAKAO S, NIIOKA M, WATANABE T, OKANO H, MATSUZAKI Y, SHIOTA G, OKAZAKI I (2007) Bone marrow-derived cells express matrix metalloproteinases and contribute to regression of liver fibrosis in mice. Hepatology 45:213-222.

IMASAWA T, UTSUNOMIYA Y, KAWAMURA T, ZHONG Y, NAGASAWA R, OKABE M, MARUYAMA N, HOSOYA T, OHNO T (2001) The potential of bone marrow-derived cells to differentiate to glomerular mesangial cells. J Am Soc Nephrol 12:1401-1409.

IMBERTI B, MORIGI M, TOMASONI S, ROTA C, CORNA D, LONGARETTI L, ROTTOLI D, VALSECCHI F, BENIGNI A, WANG J, ABBATE M, ZOJA C, REMUZZI G (2007) Insulin-like growth factor-1 sustains stem cell mediated renal repair. J Am Soc Nephrol 18:2921-2928.

INADA A, NAGAI K, ARAI H, MIYAZAKI J, NOMURA K, KANAMORI H, TOYOKUNI S, YAMADA Y, BONNER-WEIR S, WEIR GC, FUKATSU A, SEINO Y (2005) Establishment of a diabetic mouse model with progressive diabetic nephropathy. Am J Pathol 167:327-336.

ISHIKURA H, TAKAHASHI C, KANAGAWA K, HIRATA H, IMAI K, YOSHIKI T (1991) Cytokine regulation of ICAM-1 expression on human renal tubular epithelial cells in vitro. Transplantation 51:1272-1275.

ITO T, SUZUKI A, IMAI E, OKABE M, HORI M (2001) Bone marrow is a reservoir of repopulating mesangial cells during glomerular remodeling. J Am Soc Nephrol 12:2625-2635.

JERUMS G, PANAGIOTOPOULOS S, PREMARATNE E, POWER DA, MACISAAC RJ (2008) Lowering of proteinuria in response to antihypertensive therapy predicts improved renal function in late but not in early diabetic nephropathy: a pooled analysis. Am J Nephrol 28:614-627.

JIANG XX, ZHANG Y, LIU B, ZHANG SX, WU Y, YU XD, MAO N (2005) Human mesenchymal stem cells inhibit differentiation and function of monocyte-derived dendritic cells. Blood 105:4120-4126. 
KALE S, KARIHALOO A, CLARK PR, KASHGARIAN M, KRAUSE DS, CANTLEY LG (2003) Bone marrow stem cells contribute to repair of the ischemically injured renal tubule. J Clin Invest 112:42-49.

KINNAIRD T, STABILE E, BURNETT MS, LEE CW, BARR S, FUCHS S, EPSTEIN SE (2004a) Marrow-derived stromal cells express genes encoding a broad spectrum of arteriogenic cytokines and promote in vitro and in vivo arteriogenesis through paracrine mechanisms. Circ Res 94:678-685.

KINNAIRD T, STABILE E, BURNETT MS, SHOU M, LEE CW, BARR S, FUCHS S, EPSTEIN SE (2004b) Local delivery of marrow-derived stromal cells augments collateral perfusion through paracrine mechanisms. Circulation 109:1543-1549.

KOC ON, DAY J, NIEDER M, GERSON SL, LAZARUS HM, KRIVIT W (2002) Allogeneic mesenchymal stem cell infusion for treatment of metachromatic leukodystrophy (MLD) and Hurler syndrome (MPS-IH). Bone Marrow Transplant. 30:215-222..

KRAUSE D, CANTLEY LG (2005) Bone marrow plasticity revisited: protection or differentiation in the kidney tubule? J Clin Invest 115:17051708.

LANGE C, TOGEL F, ITTRICH H, CLAYTON F, NOLTE-ERNSTING C, ZANDER AR, WESTENFELDER C (2005) Administered mesenchymal stem cells enhance recovery from ischemia/reperfusion-induced acute renal failure in rats. Kidney Int 68:1613-1617.

LE BK, GOTHERSTROM C, RINGDEN O, HASSAN M, MCMAHON R, HORWITZ E, ANNEREN G, AXELSSON O, NUNN J, EWALD U, NORDEN-LINDEBERG S, JANSSON M, DALTON A, ASTROM E, WESTGREN M (2005) Fetal mesenchymal stem-cell engraftment in bone after in utero transplantation in a patient with severe osteogenesis imperfecta. Transplantation 79:1607-1614.

LE BK, RASMUSSON I, SUNDBERG B, GOTHERSTROM C, HASSAN M, UZUNEL M, RINGDEN O (2004) Treatment of severe acute graft-versushost disease with third party haploidentical mesenchymal stem cells. Lancet 363:1439-1441.

LEE RH, SEO MJ, REGER RL, SPEES JL, PULIN AA, OLSON SD, PROCKOP DJ (2006) Multipotent stromal cells from human marrow home to and promote repair of pancreatic islets and renal glomeruli in diabetic NOD/scid mice. Proc Natl Acad Sci USA 103:17438-17443.

MACCARIO R, PODESTA M, MORETTA A, COMETA A, COMOLI P, MONTAGNA D, DAUDT L, IBATICI A, PIAGGIO G, POZZI S, FRASSONI F, LOCATELLI F (2005) Interaction of human mesenchymal stem cells with cells involved in alloantigen-specific immune response favors the differentiation of CD4+ T-cell subsets expressing a regulatory/suppressive phenotype. Haematologica 90:516-525.

MARIC C, HALL JE (2011) Obesity, metabolic syndrome and diabetic nephropathy. Contrib Nephrol 170:28-35.

MATSUI $H$, SUZUKI M, TSUKUDA R, IIDA K, MIYASAKA M, IKEDA $\mathrm{H}$ (1996) Expression of ICAM-1 on glomeruli is associated with progression of diabetic nephropathy in a genetically obese diabetic rat, Wistar fatty. Diabetes Res Clin Pract 32:1-9.

MCCARTHY ET, SHARMA R, SHARMA M, LI JZ, GE XL, DILEEPAN KN, SAVIN VJ (1998) TNF-alpha increases albumin permeability of isolated rat glomeruli through the generation of superoxide. J Am Soc Nephrol 9:433-438.

MCCRARY EB (2008) The road to renal failure: an overview of diabetic nephropathy. Adv Nurse Pract 16:61-63.

MERTES H, PENNINGS G (2009) Cross-border research on human embryonic stem cells: legal and ethical considerations. Stem Cell Rev 5:10-17.

MINGUELL JJ, ERICES A, CONGET P (2001) Mesenchymal stem cells. Exp Biol Med 226:507-520.

MOCAN MC, KADAYIFCILAR S, ELDEM B (2006) Elevated intravitreal interleukin-6 levels in patients with proliferative diabetic retinopathy. Can J Ophthalmol 41:747-752.

MORA C, NAVARRO JF (2006) Inflammation and diabetic nephropathy. Curr Diab Rep 6:463-468.

MORIGI M, IMBERTI B, ZOJA C, CORNA D, TOMASONI S, ABBATE M, ROTTOLI D, ANGIOLETTI S, BENIGNI A, PERICO N, ALISON M, REMUZZI G (2004) Mesenchymal stem cells are renotropic, helping to repair the kidney and improve function in acute renal failure. J Am Soc Nephrol 15:1794-1804.

NAJAFIAN B, ALPERS CE, FOGO AB (2011) Pathology of human diabetic nephropathy. Contrib Nephrol 170:36-47.

NEUHUBER B, TIMOTHY HB, SHUMSKY JS, GALLO G, FISCHER I (2005) Axon growth and recovery of function supported by human bone marrow stromal cells in the injured spinal cord exhibit donor variations. Brain Res 1035:73-85.
NIGAM S, LIEBERTHAL W (2000) Acute renal failure. III. The role of growth factors in the process of renal regeneration and repair. Am J Physiol Renal Physiol 279:F3-F11.

NINICHUK V, KHANDOGA AG, SEGERER S, LOETSCHER P, SCHLAPBACH A, REVESZ L, FEIFEL R, KHANDOGA A, KROMBACH F, NELSON PJ, SCHLONDORFF D, ANDERS HJ (2007) The role of interstitial macrophages in nephropathy of type 2 diabetic $\mathrm{db} / \mathrm{db}$ mice. Am J Pathol 170:1267-1276.

ORTIZ-MUNOZ G, LÓPEZ-PARRA V, LÓPEZ-FRANCO O, FERNÁNDEZVIZARRA P, MALLAVIA B, FLORES C, SANZ A, BLANCO J, MEZZANO S, ORTIZ A, EGIDO J, GÓMEZ-GUERRERO C (2010) Suppressors of cytokine signaling abrogate diabetic nephropathy. J Am Soc Nephrol 21:763-772.

PACKHAM DK, IVORY SE, REUTENS AT, WOLFE R, ROHDE R, LAMBERS HH, DWYER JP, ATKINS RC, LEWIS J (2011) Proteinuria in type 2 diabetic patients with renal impairment: the changing face of diabetic nephropathy. Nephron Clin Pract 118:c331-c338.

PECOITS-FILHO R, BARANY P, LINDHOLM B, HEIMBURGER O, STENVINKEL P (2002) Interleukin-6 is an independent predictor of mortality in patients starting dialysis treatment. Nephrol Dial Transplant 17:1684-1688.

PENFORNIS A, PERSONENI E, BOROT S (2011) Evolution of devices in diabetes management. Diabetes Technol Ther 13:Suppl 1 S93-102.

PHINNEY DG, PROCKOP DJ (2007) Concise review: mesenchymal stem/ multipotent stromal cells: the state of transdifferentiation and modes of tissue repair -current views. Stem Cells 25:2896-2902.

POULSOM R, ALISON MR, COOK T, JEFFERY R, RYAN E, FORBES SJ, HUNT T, WYLES S, WRIGHT NA (2003) Bone marrow stem cells contribute to healing of the kidney. J Am Soc Nephrol 14:Suppl 1 S48-S54.

POULSOM R, FORBES SJ, HODIVALA-DILKE K, RYAN E, WYLES S, NAVARATNARASAH S, JEFFERY R, HUNT T, ALISON M, COOK T, PUSEY C, WRIGHT NA (2001) Bone marrow contributes to renal parenchymal turnover and regeneration. J Pathol 195:229-235.

PROCKOP DJ (2009) Repair of tissues by adult stem/progenitor cells (MSCs): controversies, myths, and changing paradigms. Mol Ther 17:939-946.

PRODROMIDI EI, POULSOM R, JEFFERY R, ROUFOSSE CA, POLLARD PJ, PUSEY CD, COOK HT (2006) Bone marrow-derived cells contribute to podocyte regeneration and amelioration of renal disease in a mouse model of Alport syndrome. Stem Cells 24:2448-2455.

QIAN H, YANG H, XU W, YAN Y, CHEN Q, ZHU W, CAO H, YIN Q, ZHOU H, MAO F, CHEN Y (2008) Bone marrow mesenchymal stem cells ameliorate rat acute renal failure by differentiation into renal tubular epithelial-like cells. Int J Mol Med 22:325-332.

RASMUSSON I (2006) Immune modulation by mesenchymal stem cells. Exp Cell Res 312:2169-2179.

REUTENS AT, ATKINS RC (2011) Epidemiology of diabetic nephropathy. Contrib Nephrol 170:1-7.

RIPA RS, HAACK-SORENSEN M, WANG Y, JORGENSEN E, MORTENSEN S, BINDSLEV L, FRIIS T, KASTRUP J (2007) Bone marrow derived mesenchymal cell mobilization by granulocyte-colony stimulating factor after acute myocardial infarction: results from the Stem Cells in Myocardial Infarction (STEMMI) trial. Circulation 116:I24-I30.

ROLO AP, PALMEIRA CM (2006) Diabetes and mitochondrial function: role of hyperglycemia and oxidative stress. Toxicol Appl Pharmacol 212:167178.

ROOKMAAKER MB, SMITS AM, TOLBOOM H, VAN 'T WK, MARTENS AC, GOLDSCHMEDING R, JOLES JA, VAN ZONNEVELD AJ, GRONE HJ, RABELINK TJ, VERHAAR MC (2003) Bone-marrow-derived cells contribute to glomerular endothelial repair in experimental glomerulonephritis. Am J Pathol 163:553-562.

SALMON AB, PÉREZ VI, BOKOV A, JERNIGAN A, KIM G, ZHAO H, LEVINE RL, RICHARDSON A (2009) Lack of methionine sulfoxide reductase $\mathrm{A}$ in mice increases sensitivity to oxidative stress but does not diminish life span. FASEB J 23:3601-3608.

SEMEDO P, CORREA-COSTA M, ANTONIO CM, MARÍA AVANCINI COSTA MD, NTONIA DOS RM, SHIMIZU MH, SEGURO AC, PACHECO-SILVA A, SARAIVA CAMARA NO (2009a) Mesenchymal stem cells attenuate renal fibrosis through immune modulation and remodeling properties in a rat remnant kidney model. Stem Cells 27:3063-3073.

SEMEDO P, PALASIO CG, OLIVEIRA CD, FEITOZA CQ, GONCALVES GM CENEDEZE MA, WANG PM, TEIXEIRA VP, REIS MA, PACHECOSILVA A, CAMARA NO (2009b) Early modulation of inflammation by 
mesenchymal stem cell after acute kidney injury. Int Immunopharmacol 9:677-682.

SHAW JE, SICREE RA, ZIMMET PZ (2010) Global estimates of the prevalence of diabetes for 2010 and 2030. Diabetes Res Clin Pract 87:414.

SIMONSON MS (2007) Phenotypic transitions and fibrosis in diabetic nephropathy. Kidney Int 71:846-854.

SINGH DK, WINOCOUR P, FARRINGTON K (2011) Oxidative stress in early diabetic nephropathy: fueling the fire. Nat Rev Endocrinol 7:176-184.

STOLAR M (2010) Glycemic control and complications in type 2 diabetes mellitus. Am J Med 123:S3-11.

SUGIMOTO H, MUNDEL TM, SUND M, XIE L, COSGROVE D, KALLURI $\mathrm{R}$ (2006) Bone-marrow-derived stem cells repair basement membrane collagen defects and reverse genetic kidney disease. Proc Natl Acad Sci USA 103:7321-7326.

TAKAHASHI K, TANABE K, OHNUKI M, NARITA M, ICHISAKA T, TOMODA K, YAMANAKA S (2007) Induction of pluripotent stem cells from adult human fibroblasts by defined factors. Cell 131:861-872.

TOGEL F, HU Z, WEISS K, ISAAC J, LANGE C, WESTENFELDER C (2005) Administered mesenchymal stem cells protect against ischemic acute renal failure through differentiation-independent mechanisms. Am J Physiol Renal Physiol 289:F31-F42.

TOGEL F, WEISS K, YANG Y, HU Z, ZHANG P, WESTENFELDER C (2007) Vasculotropic, paracrine actions of infused mesenchymal stem cells are important to the recovery from acute kidney injury. Am J Physiol Renal Physiol 292:F1626-F1635.

TOLAR J, NAUTA AJ, OSBORN MJ, PANOSKALTSIS MA, MCELMURRY RT, BELL S, XIA L, ZHOU N, RIDDLE M, SCHROEDER TM, WESTENDORF JJ, MCIVOR RS, HOGENDOORN PC, SZUHAI K, OSETH L, HIRSCH B, YANT SR, KAY MA, PEISTER A, PROCKOP
DJ, FIBBE WE, BLAZAR BR (2007) Sarcoma derived from cultured mesenchymal stem cells. Stem Cells 25:371-379.

TSE WT, PENDLETON JD, BEYER WM, EGALKA MC, GUINAN EC (2003) Suppression of allogeneic T-cell proliferation by human marrow stromal cells: implications in transplantation. Transplantation 75:389-397.

UCCELLI A, MORETTA L, PISTOIA V (2008) Mesenchymal stem cells in health and disease. Nat Rev Immunol 8:726-736.

VALLE-PRIETO A, CONGET PA (2010) Human mesenchymal stem cells efficiently manage oxidative stress. Stem Cells Dev 19:1885-1893.

VAZIRI ND, NORRIS K (2011) Lipid disorders and their relevance to outcomes in chronic kidney disease. Blood Purif 31:189-196.

WAGERS AJ, WEISSMAN IL (2004) Plasticity of adult stem cells. Cell 116:639-648.

WANG Z, JIANG T, LI J, PROCTOR G, MCMANAMAN JL, LUCIA S, CHUA S, LEVI M (2005) Regulation of renal lipid metabolism, lipid accumulation, and glomerulosclerosis in FVBdb/db mice with type 2 diabetes. Diabetes 54:2328-2335.

WONG CY, CHEONG SK, MOK PL, LEONG CF (2008) Differentiation of human mesenchymal stem cells into mesangial cells in post-glomerular injury murine model. Pathology 40:52-57.

YAMAGISHI S, FUKAMI K, UEDA S, OKUDA S (2007) Molecular mechanisms of diabetic nephropathy and its therapeutic intervention. Curr Drug Targets 8:952-959.

YAMAGISHI S, MATSUI T (2010) Advanced glycation end products, oxidative stress and diabetic nephropathy. Oxid Med Cell Longev 3:101108.

ZHOU H, TIAN HM, LONG Y, ZHANG XX, ZHONG L, DENG L, CHEN XH, LI XQ (2009) Mesenchymal stem cells transplantation mildly ameliorates experimental diabetic nephropathy in rats. Chin Med J 122:2573-2579. 